\title{
The prevalence and systemic risk factors of diabetic macular edema: a cross-sectional study from Turkey
}

\author{
Durgul Acan ${ }^{1 *}$, Mehmet Calan², Duygu Er ${ }^{1}$ Tugba Arkan², Nilufer Kocak', Firat Bayraktar² and Suleyman Kaynak ${ }^{1}$
}

\begin{abstract}
Background: The aim of this study was to evaluate the prevalence of diabetic macular edema (DME) utilizing optical coherence tomography (OCT), and to clarify the effects of the systemic findings and risk factors on the development of DME.

Methods: This cross-sectional study was conducted in the departments of ophthalmology and endocrinology at the Dokuz Eylul University School of Medicine in Izmir, Turkey. The demographics, type and duration of diabetes mellitus, treatment modality, smoking and alcohol consumption habits, as well as the systemic blood pressure, renal functional tests, hemoglobulin A1c level, serum lipid profile, and 24-h urine albumin level were noted and statistically analyzed. The relationships between the systemic findings and DME were studied.

Results: Four-hundred and thirteen eyes of 413 diabetic patients who were examined between January 2011 and July 2012 were enrolled in this study. The prevalence of DME was 15.3\% among the patients. The males exhibited DME significantly more frequently than the females $(p=0.031)$, and the duration of diabetes was significantly longer in those patients with DME $(p<0.001)$. Those patients without DME frequently used antihyperlipidemic drugs and had a higher level of high density lipoprotein cholesterol ( $p=0.040$ and $p=0.046$, respectively). The patient's alcohol consumption, nephropathy, neuropathy, previous cataract surgery, severity of diabetic retinopathy, and insulin usage were statistically significant factors with regard to the DME prevalence.
\end{abstract}

Conclusions: This study demonstrated the prevalence of DME in Turkey by utilizing OCT. The development of DME can be avoided or limited and the response to treatment may be improved by the regulation of the DME risk factors.

Keywords: Diabetic macular edema, Optical coherence tomography, Prevalence

\section{Background}

Since 1980, the adult population living with diabetes has increased four-fold to approximately 422 million according to the most recent World Health Organization's Global Report on Diabetes. This sharp rise can be attributed to overweight and obesity, which have resulted in an increase in type 2 diabetes [1]. The prevalence of diabetes in Turkey has recently been reported as $13.2 \%$ [2].

The most common reason for vision loss in diabetic patients is diabetic macular edema (DME). Unfortunately, the absolute prevalence of DME may be increasing due to

\footnotetext{
* Correspondence: durgul2029@hotmail.com

'Department of Ophthalmology, Dokuz Eylul University School of Medicine, Izmir, Turkey

Full list of author information is available at the end of the article
}

the overall increase in the prevalence of diabetes in industrialized nations [3]. Population-based studies have reported the prevalence of DME in type 1 diabetic patients as $4.2-7.9 \%$, while the rate for type 2 diabetes patients ranges from 1.4-12.8\% [4-27]. In a Cochrane review of the DME prevalence evaluated using optical coherence tomography $(\mathrm{OCT})$, the prevalence rates covered a wide range $(19 \%-65 \%)$ [28].

In recent years, the use of OCT has become more widespread for the objective measurement of retinal thickness and the other elements of macular edema [29-31]. The Diabetic Retinopathy Clinical Research network (DRCR. net) has adopted standard OCT DME assessments in multicenter studies of diabetic retinopathy (DR). Since this assessment is quantitative with the use of OCT, rather than 
qualitative when applying photography or biomicroscopy, this is considered to be a significant advantage.

The epidemiology and disease burden have not yet been fully elucidated, and there is limited information on the current state of DME in Turkey. Therefore, the aim of this study was to evaluate the prevalence, demographic characteristics of the patients, and systemic associations of DME utilizing OCT in Izmir, Turkey.

\section{Methods}

This cross-sectional study was conducted in the departments of ophthalmology and endocrinology at the Dokuz Eylul University School of Medicine in Izmir. A total of 413 eyes of 413 diabetic patients who were followed up in the clinics between January 2011 and July 2012 were enrolled. The demographic data, diabetes type, diabetic age, treatment modality, smoking and alcohol consumption habits, as well as the systemic blood pressure, renal functional test results, hemoglobulin A1c (HbA1c) level, serum lipid profile, 24-h urine albumin level, and the existence of neuropathy were noted and statistically analyzed. The ophthalmological evaluation of each participant included the best corrected visual acuity (BCVA), slit-lamp biomicroscopy, intraocular pressure (IOP) measurement, and dilated fundoscopy. Fluorescein angiography and a central macular thickness (CMT) analysis with OCT were also performed. The relationships between the systemic findings and the prevalence of DME were studied.

Those patients $\geq 18$ years old with type 1 or 2 diabetes diagnosed by an endocrinologist at the Dokuz Eylul University Hospital Endocrinology Clinic between January 2011 and July 2012, who were then referred to the Ophthalmology Department Retina Unit for DME and DR screenings, were included in this study.

The exclusion criteria were as follows: eyes with an ocular abnormality other than DME (vitreomacular traction, epiretinal membrane, etc.) and media opacities interfering with the reliability of OCT imaging (dense cataract, uveitis, etc.), and those patients with insufficient data for the study protocol.

\section{Ophthalmological examination}

The BCVA was evaluated using the Bailey-Lovie chart after correcting for refractive errors. An anterior segment examination was conducted using slit-lamp biomicroscopy and dilated fundoscopy. The IOP was obtained with a Goldmann applanation tonometer, and Heidelberg retinal angiography (HRA) and OCT were performed using the Spectralis HRA-OCT II (Heidelberg, Germany). After obtaining a fixation point for the patient, 6 OCT shots were lined up with the radial line scan and each other at an angle of $30^{\circ}$. The eyes were evaluated for clinically significant macular edema
(CSME) as defined by the Early Treatment Diabetic Retinopathy Study (ETDRS) and with a central macular thickness (CMT) (mean thickness at the point of the intersection of 6 radial scans) via OCT $\geq 250 \mu \mathrm{m}$ attributable to DME [32].

\section{Statistical analysis}

The data from all of the subjects who fulfilled the inclusion/exclusion criteria were analyzed using SPSS 16.0 software. For the descriptive analysis, the mean, standard deviation, and percentage were used. The chi-squared test, Fisher's exact test, and t-test were applied for the univariate analysis. A $p$ value $<0.05$ was considered to be statistically significant.

\section{Results}

Of the 425 patients who met the study criteria, 413 were included for evaluation. DME was detected in $15.3 \%$ (63) of the patients and DR was determined in 32\% (132) of the patients. Moreover, DME was found in $14.8 \%$ (4) of the patients with type 1 diabetes and in $15.3 \%$ (59) of the patients with type 2 diabetes $(p=0.604)$. Of the 63 DME patients, 15 received previous focal/grid laser treatments, 8 received previous intravitreal anti-vascular endothelial growth factor (VEGF) or steroid treatments, and 5 received previous combined focal/grid laser and anti-VEGF/steroid treatments. In addition, 9 patients without DME received previous focal/grid treatments and one patient underwent a vitrectomy.

The demographic and laboratory characteristics of the patients are summarized in Table 1. DME was significantly more prevalent in the males than the females ( $p=$ 0.031 ), and the male subjects had higher HbA1c levels than the female subjects $(8.30 \pm 2.25 \%$ and $7.89 \pm 2.13 \%$, respectively) $(p=0.054)$. Although there was no direct statistical correlation between the HbA1c levels and DME, a significant increase in the frequency of DME was observed particularly in those subjects with HbA1c values of $7.0 \%$ or more $(p=0.037)$. While the type of diabetes did not have an effect on DME, the duration of diabetes was significantly longer in the DME patients, particularly in those diagnosed between 10 and 20 years previously $(p<0.001)$. Those patients without DME were determined to have a significantly higher rate of antihyperlipidemic drug usage and a higher level of high density lipoprotein cholesterol (HDL-C) $(p=0.040$ and $p=0.046$, respectively). The mean serum creatinine levels in those patients with and without DME were 1.13 $\pm 0.81 \mathrm{mg} / \mathrm{dL}$ and $0.87 \pm 0.63 \mathrm{mg} / \mathrm{dL}$, respectively, and this difference was statistically significant $(p=0.021)$.

In the comparison of the normoalbuminuric, microalbuminuric, and macroalbuminuric patients in terms of the DME frequency, a statistically significant difference was seen between the 3 groups $(p<0.001)$. While $11.0 \%$ 
Table 1 Comparison of the demographic and laboratory characteristics of the patients with and without DME

\begin{tabular}{|c|c|c|c|}
\hline Characteristics & $\begin{array}{l}\text { Patients with DME } \\
(n=63,15.3 \%)\end{array}$ & $\begin{array}{l}\text { Patients without DME } \\
(n=350,84.7 \%)\end{array}$ & $P$ value \\
\hline Age (years) & $58.86 \pm 11.27$ & $56.03 \pm 11.95$ & 0.082 \\
\hline Gender (female/male) & $26 / 37$ & 196/154 & $0.031^{*}$ \\
\hline $\mathrm{BMI}\left(\mathrm{kg} / \mathrm{m}^{2}\right)$ & $29.25 \pm 5.78$ & $29.46 \pm 5.80$ & 0.797 \\
\hline Type of diabetes $(1 / 2)$ & $4 / 59$ & $23 / 327$ & 0.604 \\
\hline Duration of diabetes (years) & $16.77 \pm 8.16$ & $7.64 \pm 7.12$ & $<0.001^{*}$ \\
\hline \multicolumn{4}{|l|}{$\mathrm{DR}(\mathrm{n})$} \\
\hline Mild-moderate DR & $18(28.6 \%)$ & $52(14.9 \%)$ & \multirow[t]{3}{*}{$<0.001^{*}$} \\
\hline Severe-very severe & $10(15.9 \%)$ & $6(1.7 \%)$ & \\
\hline PDR & $35(55.5 \%)$ & $11(3.1 \%)$ & \\
\hline Smoking $(n=97,23.5 \%)$ & $12(19 \%)$ & $85(24.2 \%)$ & 0.367 \\
\hline Alcohol $(n=10,2.4 \%)$ & $5(7.9 \%)$ & $5(1.4 \%)$ & $0.010^{*}$ \\
\hline Hypertension ( $n=242,58.5 \%)$ & $42(66.6 \%)$ & $200(57.1 \%)$ & 0.158 \\
\hline Systolic blood pressure $(\mathrm{mmHg})$ & $130.37 \pm 20.15$ & $128.56 \pm 17.86$ & 0.469 \\
\hline Diastolic blood pressure (mmHg) & $79.25 \pm 8.87$ & $79.05 \pm 9.91$ & 0.881 \\
\hline Anti-hyperlipidemic drug usage $(n=109,26.4 \%)$ & $10(15.9 \%)$ & $99(28.3 \%)$ & $0.040^{*}$ \\
\hline $\operatorname{CVD}(n=78,18.9 \%)$ & $16(25.4 \%)$ & $62(17.7 \%)$ & 0.152 \\
\hline Peripheral neuropathy $(n=209,50.6 \%)$ & $42(66.6 \%)$ & $167(47.7 \%)$ & $0.006^{*}$ \\
\hline Nephropathy $(n=99,24.0 \%)$ & $28(44.4 \%)$ & $71(20.3 \%)$ & $<0.001^{*}$ \\
\hline Normoalbuminuria $(n=314,76 \%)$ & $35(55.5 \%)$ & 279 (79.7\%) & \multirow[t]{3}{*}{$<0.001^{*}$} \\
\hline Microalbuminuria $(n=69,16.7 \%)$ & $20(31.7 \%)$ & $49(14 \%)$ & \\
\hline Macroalbuminuria $(n=30,7.3 \%)$ & $8(12.7 \%)$ & $22(6.2 \%)$ & \\
\hline $\mathrm{HbA1c}(\%)$ & $8.39 \pm 1.97$ & $8.02 \pm 2.23$ & 0.226 \\
\hline FBG (mg/dL) & $164.50 \pm 57.86$ & $157.50 \pm 65.84$ & 0.523 \\
\hline Creatinine (mg/dL) & $1.13 \pm 0.81$ & $0.87 \pm 0.63$ & $0.021^{*}$ \\
\hline GFR $\left(\mathrm{mL} / \mathrm{min} / 1.73 \mathrm{~m}^{2}\right)$ & $76.21 \pm 28.82$ & $88.25 \pm 22.35$ & $0.002^{*}$ \\
\hline Total cholesterol (mg/dL) & $187.95 \pm 41.75$ & $194.00 \pm 50.72$ & 0.372 \\
\hline $\mathrm{LDL}-\mathrm{C}(\mathrm{mg} / \mathrm{dL})$ & $114.44 \pm 33.76$ & $117.85 \pm 36.72$ & 0.494 \\
\hline $\mathrm{HDL}-\mathrm{C}(\mathrm{mg} / \mathrm{dL})$ & $40.19 \pm 11.87$ & $43.45 \pm 11.92$ & $0.046^{*}$ \\
\hline Triglyceride (mg/dL) & $165.24 \pm 86.87$ & $158.52 \pm 113.69$ & 0.656 \\
\hline
\end{tabular}

Results are given as the mean \pm SD. A $p$ value of $<0.05$ was considered to be significant $(*)$. BMI body mass index, CVD cardiovascular disease, CMT central macular thickness, $D R$ diabetic retinopathy, $H b A 1$ hemoglobin A1c, GFR glomerular filtration rate, FBG fasting blood glucose, $H D L-C$ high density lipoprotein cholesterol, $L D L-C$ low density lipoprotein cholesterol, PDR proliferative diabetic retinopathy

of the patients without nephropathy had DME, $29.0 \%$ of patients with microalbuminuria and $26.7 \%$ of the patients with macroalbuminuria had DME $(p<0.001)$. Peripheral neuropathy was also significantly frequent in those patients with DME $(p=0.006)$. The mean BCVAs of the eyes with and without DME were $0.55 \pm 0.59 \log$ MAR and $0.04 \pm 0.10 \operatorname{logMAR}$, respectively $(p<0.001)$. The mean IOPs of the eyes with and without DME were $14.91 \pm 2.45 \mathrm{mmHg}$ and $15.12 \pm 2.64 \mathrm{mmHg}$, respectively, and no statistical difference was seen $(p=0.562)$.

The prevalence of DME was $28.6 \%$ in those patients with mild to moderate non-proliferative diabetic retinopathy (NPDR) and $72.6 \%$ in those patients with severe NPDR to proliferative diabetic retinopathy (PDR) $(p<0.001)$. The DME prevalences in the phakic and pseudophakic eyes were $12.9 \%$ (49) and $43.7 \%$ (14), respectively $(p<0.001)$. Assuming the possible effects of cataract surgery on DME and evaluating only the phakic patients showed that the duration of diabetes, nephropathy, neuropathy, and antihyperlipidemic drug use significantly affected the DME in similar ways $(p<0.001, p=0.020, p=0.012$, and $p=0.038$, respectively). However, in the phakic patients, the gender, creatinine level, and HDL-C level did not have statistically significant effects on the DME $(p=0.610, p=0.227$, and $p=0.233$, respectively). 


\section{Discussion}

There is a known increasing worldwide prevalence of DME. Correspondingly, an increase in diabetes-related complications is expected with the increase in diabetes mellitus cases in Turkey. In one study from Turkey, the prevalence of DME was found to be $14.2 \%$ in the preOCT era [33]. Most studies have used non-stereoscopic fundus photography; therefore, the accuracy of the DME assessment is in doubt. The use of stereoscopic slit-lamp biomicroscopy alone may also lead to both the underdiagnosis and overdiagnosis of DME. Macular edema was defined using the CSME criteria in approximately onehalf of the previous studies, and thus, only covered the more severe DME spectrum. The clinical use of OCT has enabled the detection of DME that was previously overlooked in a stereoscopic fundus examination. When compared to a clinical examination, the OCT detection and assessment of DME is more objective and reproducible, ensuring greater uniformity in the interventions applied and the treatment outcomes when compared to the pre-OCT era [34, 35]. According to DRCR.net, for DME trial inclusion and retreatment eligibility, the central subfield mean thickness on a Stratus OCT must be $\geq 250 \mu \mathrm{m}$. The current study used the Spectralis HRAOCT II, which produces high resolution histological macular images, and the prevalence of DME was found to be $15.3 \%$. This ratio was higher than the prevalence in a previous study conducted in 2006, and thus supports the sensitivity of the OCT.

The DME prevalence is related to the disease duration. In the present study, the prevalence of DME was $2.8 \%$ within 5 years of the diabetes diagnosis and $22.0 \% 5$ years after the diagnosis $(p<0.001)$. After 10 years, the prevalence rose prominently. In a study by Aiello et al. [36], the prevalence was $5 \%$ within the first 5 years after the diagnosis and $15 \%$ at 15 years.

The males in this study exhibited DME more frequently than the females, and the odds ratio (OR) for the males was 1.811 (95\% CI: $1.051<\mathrm{OR}<3.121) \quad(p=0.031)$. In addition, the HbA1c levels were significantly higher in the males than the females; therefore, and it can be suggested that not only gender, but also worse diabetic control in male patients can indicate a higher prevalence of DME. The HbA1c level in the patients with DME $(8.39 \pm 1.97 \%)$ was slightly higher than that in the patients without DME $(8.02 \pm 2.23 \%)$, but this difference was not statistically significant $(p=0.226)$. The prevalences of DME in those patients with HbA1c levels $<7.0 \%$ and $\geq 7.0 \%$ were $10.62 \%$ and $18.18 \%$, respectively $(p=0.037)$. In the Diabetes Control and Complications Trial (DCCT), it was shown that the strict control of blood glucose in type 1 diabetes patients led to a $29 \%$ decrease in the cumulative incidence of macular edema at the 9-year follow-up, and halved the application of focal laser treatment for DME [37, 38]. Even if there is a deterioration in control later in life, the effects of improved glycemic control sustained over many years have been shown to persist. In the Epidemiology of Diabetes Interventions and Complications (EDIC) study, which was an extension of the DCCT in which the level of glycemic control of the former intensive and conventional control groups converged, it was reported that the former intensive control group continued to fare better than the former conventional control group. Four years after the end of the DCCT, the CSME incidence was $2 \%$ in the former intensive control group, compared to the $8 \%$ rate in the former conventional control group $(p<0.001)$ [39].

In the UK Prospective Diabetes Study, an analogous, randomized clinical trial of type 2 diabetes patients, it was reported that strict blood glucose control resulted in a $29 \%$ reduction in laser treatment in a follow-up period of 10 years; of the laser treatments required, $78 \%$ were for DME [40]. In the current study, the prevalence of DME was conspicuously higher in the insulin-taking patients $(p<0.000)$. In previous studies, taking insulin has been reported to trigger the development of DME in the acute period. In this period, the hypoxia-inducible factor connects to the VEGF promotor region, and the VEGF transcription increases. Subsequently, the blood-retina barrier breaks down and permeability increases with the activation of protein kinase C. In the chronic period, insulin shows anti-inflammatory and anti-apoptotic effects and reduces oxidative stress [41]. The high prevalence of DME in the insulin-taking patients in the present study may be the result of the poor glycemic control in these patients.

The UK Prospective Diabetes Study also reported that the mean systolic blood pressure was reduced by $10 \mathrm{mmHg}$ and the diastolic blood pressure was reduced by $5 \mathrm{mmHg}$ in a median follow-up period of 8.4 years, which resulted in a $35 \%$ decrease in the retinal laser treatments, $78 \%$ of which were for DME [42]. In addition, the Wisconsin Epidemiologic Study of Diabetic Retinopathy determined that systemic hypertension increased the prevalence of DME 3-fold. It has been suggested that not only is hypertension a risk factor for macular edema development, but the treatment may have important benefits in patients with uncontrolled hypertension [43]. In the current study, the prevalences of DME in those patients with and without systemic hypertension were $17.4 \%$ and $12.3 \%$, respectively $(p=0.158)$. In addition, there was no statistically significant difference with respect to the systolic and diastolic blood pressure levels between those patients with and without DME. However, anti-hypertensive medications may affect these results. The beneficial effects of anti-hypertensive medications that target the reninangiotensin-aldosterone system (RAAS) in DR and DME have been evaluated in several clinical trials, such as the 
Diabetic Retinopathy Candesartan Trials (DIRECT) and Renin-Angiotensin System Study (RASS).

A recent meta-analysis revealed that patients with DME or PDR were more likely to have incident cardiovascular disease (CVD) and fatal CVD when compared to those without DME or PDR in type 2 diabetes mellitus [44]. It is accepted that fluid retention due to cardiac failure, or another CVD can exacerbate DME and may be an important concern when managing it [45]. In the present study, DME was detected in $20.5 \%$ (16) of the patients with type 2 diabetes and CVD and in 14.0\% (43) of those without CVD, but the difference was not statistically significant $(p=0.151)$. However, the patients were not examined by a cardiologist, the subclinical findings may not have been noticed, and/or the patients may not have been aware of their CVD.

The prevalence of DME was significantly higher in those patients who consumed alcohol $(50 \%)(p=0.010)$. In the advanced analysis, alcohol consumption was seen to increase the odds-relative risk 5.95-fold (95\% CI: 1.67 < OR $<21.19)$. This could be due to the deleterious effects of alcohol on glycemic control or because of the compromised treatment compliance in patients who drink regularly. However, in a previous study from Turkey, there was no significant correlation between alcohol consumption and the prevalence of DME [33].

Dyslipidemia has been implicated as an independent risk factor for vision loss and DME [46-48]; however, no single lipid measure has been found to be consistently associated with DR or DME [49]. Of the recent studies, only the Madrid Diabetes Study determined an association between low density lipoprotein cholesterol (LDLC) and DR incidence [50]. In the current study, the HDL-C was significantly lower in the patients with DME $(p=0.046)$. Moreover, the prevalences of DME in the patients who were and were not using antihyperlipidemic drugs were $9.2 \%$ and $17.4 \%$, respectively $(p=0.040)$. Of the 109 patients using antihyperlipidemic drugs, 106 were taking statins. In a 2004 study, it was reported that the atorvastatin in statins reduced the severity of hard exudates and the migration of subfoveal lipids in CSME in dyslipidemic type 2 diabetic patients [51]. In another study from Greece, the use of atorvastatin reduced the severity of hard exudates and fluorescein leakage in diabetic maculopathy in dyslipidemic diabetic patients [52]. In DME-associated lipid exudates, there will generally be a spontaneous resolution over 2 years or longer [53]. Macrophages clear the exudates by phagocytosis [54], and the clearance of lipid exudates in DME can be independently accelerated by serum lipid control and by focal/grid photocoagulation [51]. With decreasing serum lipid levels, statins are also thought to reduce inflammation and secondary microvascular leukocytosis [54]. In contrast, one meta-analysis reported the dose-dependent relationship between statin use and an increased risk of diabetes [55]. This led to the belief that statins might influence glucose homeostasis by decreasing insulin production or increasing insulin resistance, or both [56]. Consequently, the effects of statins on diabetes and DME remain controversial.

The mean serum creatinine levels in patients with and without DME were $1.13 \pm 0.81 \mathrm{mg} / \mathrm{dl}$ and $0.87 \pm$ $0.63 \mathrm{mg} / \mathrm{dl}$, respectively, and this difference was statistically significant $(p=0.021)$. While $11 \%$ of the patients without nephropathy had DME, $29.0 \%$ of the patients with microalbuminuria and $26.7 \%$ of patients with macroalbuminuria did $(p<0.001)$. In a 15 -year follow-up study, the development of macroalbuminuria was found to be associated with the development of DME in type 1 diabetes [57]. In this study, not only macroalbuminuria, but also microalbuminuria was associated with DME.

The major ocular risk factor associated with DME is DR severity. Although DME can be seen at any level of DR, an increasing DR severity has been associated with an increasing prevalence of DME [58-62]. In one study, the 14-year incidence of DME increased from $25 \%$ to $37 \%$ as the baseline retinopathy severity increased from mild to moderate NPDR [60]. In addition, point estimates of $4 \%$ and $15 \%$ for the prevalence of subclinical DME in mild to moderate NPDR and severe NPDR to PDR, respectively, have been reported. In this study, the DME prevalence rate was $28.6 \%$ in those patients with mild-moderate NPDR, while it was $72.6 \%$ in those patients with severe NPDR to PDR $(p<0.001)$.

Starling's law explains the balance between intravascular and extravascular liquid passage. Based on this, a study published decades ago advocated the idea that high IOP levels protect against the development of exudates [62]. However, there has not yet been enough research done in this regard. In this study, the mean IOPs in those eyes with and without DME were $14.91 \pm 2.45 \mathrm{mmHg}$ and $15.12 \pm 2.64 \mathrm{mmHg}$, respectively, but the difference was not statistically significant $(p=0.562)$. Although the findings are inconsistent, diabetes has been found to be a risk factor for developing primary glaucoma in some population-based studies [63]. For instance, the Singapore Malay Eye Study found an association between ocular hypertension and diabetes, but not glaucoma [64].

Diabetes is associated with the early and rapid development of cataracts, and cataract surgery, other types of intraocular surgery, and ocular inflammatory disease may produce inflammatory and angiogenic mediators that can produce macular edema in eyes with or without DR [65-69]. In accordance with this, in the present study, the DME prevalences in the phakic and pseudophakic eyes were $12.9 \%(49)$ and $43.7 \%(14)$, respectively $(p<0.001)$. 


\section{Conclusions}

In 2010, the prevalence of diabetes in Turkey was $13.7 \%$ as reported in the Turkish Diabetes Epidemiology II (TURDEP-II) study. In the USA, DR is the leading cause of blindness in individuals aged $<60$ years old, and DME is the most common cause of visual loss in those with DR $[56,66]$. Fortunately, permanent vision loss can be prevented by the early diagnosis and treatment of DME. The DME prevalence has been reported at a wide range of rates in numerous studies in the literature, but there have been no previous studies in Turkey on this topic. The development of DME may be avoided or limited and the response to treatment may be improved by the regulation of the DME risk factors. In this study, the prevalence of DME was associated with male gender, diabetes duration, $\mathrm{HbA} 1 \mathrm{c} \geq 7.0 \%$, insulin usage, alcohol consumption, low HDL-C levels, nephropathy, neuropathy, severity of DR, and previous cataract surgery. However, antihyperlipidemic drugs may be protective against DME. The cross-sectional design could be considered a limitation of this study; therefore, longitudinal studies with more subjects are needed.

\section{Abbreviations}

BCVA: Best corrected visual acuity; CMT: Central macular thickness; CSME: Clinically significant macular edema; DCCT: Diabetes Control and Complications Trial; DIRECT: Diabetic Retinopathy Candesartan Trials; DME: Diabetic macular edema; DR: Diabetic retinopathy; DRCR.net: Diabetic Retinopathy Clinical Research network; EDIC: Epidemiology of Diabetes Interventions and Complications; HbA1c: Hemoglobin A1c; HDL-C: High density lipoprotein cholesterol; IOP: Intraocular pressure; LDL-C: Low density lipoprotein cholesterol; NPDR: Non-proliferative diabetic retinopathy; OCT: Optical coherence tomography; PDR: Proliferative diabetic retinopathy; RAAS: Renin-angiotensin-aldosterone system; RASS: Renin-Angiotensin System Study; VEGF: Vascular endothelial growth factor

\section{Acknowledgements}

None.

\section{Funding}

None.

\section{Availability of data and materials}

The datasets generated and/or analyzed during the current study are available from the corresponding author upon reasonable request.

\section{Authors' contributions}

DA: 1st author, conception and design, data collection, analysis and interpretation, writing the manuscript, critical revision of the manuscript, and statistical expertise. MC, DE, and TA: data collection. NK and SK: analysis and interpretation, writing the manuscript, and critical revision of the manuscript. FB: conception and design. All authors read and approved the final manuscript.

\section{Ethics approval and consent to participate}

This study was conducted with approval from the Local Ethics Committee of the Dokuz Eylul University (reference number: 572GA). Administrative permission was granted to access the patient database. The patients provided informed consent for the use of their information in this research.

Consent for publication

Not applicable.

\section{Competing interests}

The authors declare that they have no competing interests.

\section{Publisher's Note}

Springer Nature remains neutral with regard to jurisdictional claims in published maps and institutional affiliations.

\section{Author details}

${ }^{1}$ Department of Ophthalmology, Dokuz Eylul University School of Medicine, Izmir, Turkey. ${ }^{2}$ Department of Endocrinology and Metabolism, Dokuz Eylul

University School of Medicine, Izmir, Turkey.

Received: 5 August 2017 Accepted: 29 March 2018

Published online: 12 April 2018

\section{References}

1. Global report on diabetes. World Health Organization, Geneva. 2016. http:// www.who.int/diabetes/global-report/en/.

2. Diabetes country profiles. World Health Organization, Geneva. 2016. http:// www.who.int/diabetes/country-profiles/en/.

3. Cugati S, Kifley A, Mitchell P, Wang JJ. Temporal trends in the age-specific prevalence of diabetes and diabetic retinopathy in older persons: population-based survey findings. Diabetes Res Clin Pract. 2006;74:301-8.

4. Pedro RA, Ramon SA, Marc BB, Juan FB, Isabel MM. Prevalence and relationship between diabetic retinopathy and nephropathy, and its risk factors in the north-east of Spain, a population-based study. Ophthalmic Epidemiol. 2010;17:251-65.

5. Bertelsen G, Peto T, Lindekleiv H, Schirmer H, Solbu MD, Toft I, Sjølie AK, Niølstad I. Tromsø eye study: prevalence and risk factors of diabetic retinopathy. Acta Ophthalmol. 2013;91:716-21.

6. Knudsen LL, Lervang HH, Lundbye-Christensen S, Gorst-Rasmussen A. The north Jutland county diabetic retinopathy study: population characteristics. Br J Ophthalmol. 2006;90:1404-9.

7. Roy MS, Klein R, O'Colmain BJ, Klein BE, Moss SE, Kempen JH. The prevalence of diabetic retinopathy among adult type 1 diabetic persons in the United States. Arch Ophthalmol. 2004:122:546-51.

8. Kempen JH, O'Colmain BJ, Leske MC, Haffner SM, Klein R, Moss SE, Taylor HR, Hamman RF, Eye Diseases Prevalence Research Group. The prevalence of diabetic retinopathy among adults in the United States. Arch Ophthalmol. 2004;122:552-63.

9. Zhang X, Saaddine JB, Chou CF, Cotch MF, Cheng YJ, Geiss LS, Gregg EW, Albright $A L$, Klein BE, Klein R. Prevalence of diabetic retinopathy in the United States, 2005-2008. JAMA. 2010;304:649-56.

10. Jee $D$, Lee WK, Kang S. Prevalence and risk factors for diabetic retinopathy: the Korea National Health and nutrition examination survey 2008-2011. Invest Ophthalmol Vis Sci. 2013;54:6827-33.

11. Raman R, Rani PK, Reddi Rachepalle S, Gnanamoorthy P, Uthra S, Kumaramanickavel G, Sharma T. Prevalence of diabetic retinopathy in India: Sankara Nethralaya diabetic retinopathy epidemiology and molecular genetics study report 2. Ophthalmology. 2009;116:311-8.

12. Zheng $Y$, Lamoureux EL, Lavanya R, Wu R, Ikram MK, Wang JJ, Mitchell P, Cheung N, Aung T, Saw SM, Wong TY. Prevalence and risk factors of diabetic retinopathy in migrant Indians in an urbanized society in Asia: the Singapore Indian eye study. Ophthalmology. 2012;119:2119-24.

13. Al Ghamdi AH, Rabiu M, Hajar S, Yorston D, Kuper H, Polack S. Rapid assessment of avoidable blindness and diabetic retinopathy in Taif, Saudi Arabia. Br J Ophthalmol. 2012;96:1168-72.

14. Dehghan $\mathrm{MH}$, Katibeh $\mathrm{M}$, Ahmadieh $\mathrm{H}$, Nourinia R, Yaseri M. Prevalence and risk factors for diabetic retinopathy in the 40 to 80 year-old population in Yazd, Iran: the Yazd eye study. J Diabetes. 2015;7:139-41.

15. Thapa R, Joshi DM, Rizyal A, Maharjan N, Joshi RD. Prevalence, risk factors and awareness of diabetic retinopathy among admitted diabetic patients at a tertiary level hospital in Kathmandu. Nepal J Ophthalmol 2014;6:24-30.

16. Kahloun R, Jelliti B, Zaouali S, Attia S, Ben Yahia S, Resnikoff S, Khairallah M. Prevalence and causes of visual impairment in diabetic patients in Tunisia, North Africa. Eye. 2014;28:986-91

17. Mathenge W, Bastawrous A, Peto T, Leung I, Yorston D, Foster A, Kuper $\mathrm{H}$. Prevalence and correlates of diabetic retinopathy in a populationbased survey of older people in Nakuru, Kenya. Ophthalmic Epidemiol. 2014;21:169-77. 
18. Sharew G, llako DR, Kimani K, Gelaw Y. Prevalence of diabetic retinopathy in Jimma University Hospital, Southwest Ethiopia. Ethiop Med J. 2013;51:105-13.

19. Wong TY, Cheung N, Tay WT, Wang JJ, Aung T, Saw SM, Lim SC, Tai ES, Mitchell P. Prevalence and risk factors for diabetic retinopathy: the Singapore Malay eye study. Ophthalmology. 2008;115:1869-75.

20. Al-Rubeaan K, Abu El-Asrar AM, Youssef AM, Subhani SN, Ahmad NA, Al-Sharqawi AH, Alquwaihes A, Alotaibi MS, Al-Ghamdi A, Ibrahim HM. Diabetic retinopathy and its risk factors in a society with a type 2 diabetes epidemic: a Saudi National Diabetes Registry-based study. Acta Ophthalmol. 2015;93:e140-7.

21. Pugliese G, Solini A, Zoppini G, Fondelli C, Zerbini G, Vedovato M, Cavalot F, Lamacchia O, Buzzetti R, Morano S, Nicolucci A, Penno G, Renal Insufficiency and Cardiovascular Events (RIACE) Study Group. High prevalence of advanced retinopathy in patients with type 2 diabetes from the renal insufficiency and cardiovascular events (RIACE) Italian multicenter study. Diabetes Res Clin Pract. 2012;98:329-37.

22. Dutra Medeiros M, Mesquita E, Papoila AL, Genro V, Raposo JF. First diabetic retinopathy prevalence study in Portugal: RETINODIAB study-evaluation of the screening programme for Lisbon and Tagus Valley region. $\mathrm{Br} J$ Ophthalmol. 2015;99:1328-33.

23. Nathoo N, Ng M, Rudnisky CJ, Tennant MT. The prevalence of diabetic retinopathy as identified by teleophthalmology in rural Alberta. Can J Ophthalmol. 2010;45:28-32.

24. Esteves JF, Kramer CK, Azevedo MJ, Stolz AP, Roggia MF, Larangeira A, Miozzo SA, Rosa C, Lambert JH, Pecis M, Rodriques TC, Canani LH. Prevalence of diabetic retinopathy in patients with type 1 diabetes mellitus. Rev Assoc Med Bras. 2009;55:268-73.

25. Villena JE, Yoshiyama CA, Sanchez JE, Hilario NL, Merin LM. Prevalence of diabetic retinopathy in Peruvian patients with type 2 diabetes: results of a hospital-based retinal telescreening program. Rev Panam Salud Publica. 2011;30:408-14.

26. Thomas RL, Distiller L, Luzio SD, Chowdhury SR, Melville VJ, Kramer B, Owens DR. Ethnic differences in the prevalence of diabetic retinopathy in persons with diabetes when first presenting at a diabetes clinic in South Africa. Diabetes Care. 2013;36:336-41.

27. Kaidonis G, Mills RA, Landers J, Lake SR, Burdon KP, Craig JE. Review of the prevalence of diabetic retinopathy in indigenous Australians. Clin Exp Ophthalmol. 2014;42:875-82.

28. Virgili G, Menchini F, Murro V, Peluso E, Rosa F, Casazza G. Optical coherence tomography $(\mathrm{OCT})$ for detection of macular oedema in patients with diabetic retinopathy. Cochrane Database Syst Rev. 2011;7:CD008e081.

29. Koozekanani D, Roberts C, Katz SE, Herderick EE. Intersession repeatability of macular thickness measurements with the Humphrey 2000 OCT. Invest Ophthalmol Vis Sci. 2000;41:1486-91.

30. Hee MR, Puliafito CA, Wong C, et al. Quantitative assessment of macular edema with optical coherence tomography. Arch Ophthalmol. 1995:113:1019-29.

31. Hee MR, Puliafito CA, Duker JS, Reichel E, Coker JG, Wilkins JR, Schuman JS, Swanson EA, Fujimoto JG. Topography of diabetic macular edema with optical coherence tomography. Ophthalmology. 1998;105:360-70.

32. Early Treatment Diabetic Retinopathy Study Research Group. Photocoagulation for diabetic macular edema. Early treatment diabetic retinopathy study report number 1. Arch Ophthalmol. 1985;103:1796-806.

33. Taş A, Bayraktar MZ, Erdem Ü, Sobacı G, Açıkel C, Durukan AH, Karagül S. Diyabetik hastalarda retinopati gelişimine etki eden risk faktörlerinin değerlendirilmesi: çok merkezli çalışma (Türkiye'de Diyabetik Retinopati Epidemiyolojisi Araştırma Grubu). Gülhane Tıp Dergisi. 2006;48:94-100.

34. Browning DJ, McOwen MD, Bowen RM Jr, O'Marah TL. Comparison of the clinical diagnosis of diabetic macular edema with diagnosis by optical coherence tomography. Ophthalmology. 2004;111:712-5.

35. Brown JC, Solomon SD, Bressler SB, Schachat AP, DiBernardo C, Bressler NM. Detection of diabetic foveal edema; contact lens biomicroscopy compared with optical coherence tomography. Arch Ophthalmol. 2004;122:330-5.

36. Aiello LP, Gardner TW, King GL, Blankenship G, Cavallerano JD, Ferris FL III. Diabetic retinopathy. Diabetes Care. 1998;21:143-56.

37. Diabetes Control and Complications Trial Research Group. Progression of retinopathy with intensive versus conventional treatment in the diabetes control and complications trial. Ophthalmology. 1995;102:647-61.

38. Diabetes Control and Complications Trial Research Group. Early worsening of diabetic retinopathy in the diabetes control and complications trial. Arch Ophthalmol. 1998;116:874-86.
39. The writing team for the diabetes control and complications trial/ epidemiology of diabetes interventions and complications research group. Effect of intensive therapy on the microvascular complications of type 1 diabetes mellitus. JAMA. 2002;287:2563-9.

40. UK Prospective Diabetes Study (UKPDS) Group. Intensive blood-glucose control with sulphonylureas or insulin compared with conventional treatment and risk of complications in patients with type 2 diabetes (UKPDS 33). Lancet. 1998;352:837-53.

41. Jacot $J$, Vinik Al. Diabetic retinopathy: unraveling the paradoxical effects of intensive insulin treatment. Insulin. 2006;2(1):4-11.

42. UK Prospective Diabetes Study Group. Tight blood pressure control and risk of macrovascular and microvascular complications in type 2 diabetes: UKPDS 38. BMJ. 1998:317:703-14.

43. Bresnick GH. Diabetic macular edema. A review. Ophthalmology. 1986;93:989-97.

44. Xie J, Ikram MK, Cotch MF, Klein B, Varma R, Shaw JE, Klein R, Mitchell P, Lamoureux EL, Wong TY. Association of diabetic macular edema and proliferative diabetic retinopathy with cardiovascular disease: a systematic review and meta-analysis. JAMA Ophthalmol. 2017;135(6):586-93.

45. Early Treatment Diabetic Retinopathy Study Research Group. Treatment techniques and clinical guidelines for photocoagulation of diabetic macular edema. Early treatment diabetic retinopathy study report number 2 . Ophthalmology. 1987;94:761-74.

46. Miljanovic B, Glynn RJ, Nathan DM, et al. A prospective study of serum lipids and risk of diabetic macular edema in type 1 diabetes. Diabetes. 2004;53:2883-92

47. The DCCT Research Group. Effects of intensive diabetes therapy on neuropsychological function in adults in the diabetes control and complications trial. Ann Intern Med. 1996;124:379-88.

48. Ferris FL 3rd, Chew EY, Hoogwerf BJ. Serum lipids and diabetic retinopathy. Early treatment diabetic retinopathy study research group. Diabetes Care. 1996;19:1291-3.

49. Ding J, Wong TY. Current epidemiology of diabetic retinopathy and diabetic macular edema. Curr Diab Rep. 2012;12:346-54.

50. Salinero-Fort MA, San Andres-Rebollo FJ, de Burgos-Lunar C, ArrietaBlanco FJ, Gomez-Campelo P. MADIABETES group. Four-year incidence of diabetic retinopathy in a Spanish cohort: the MADIABETES study. PLoS One. 2013;8:e76417

51. Gupta A, Gupta V, Thapar S, Bhansali A. Lipid-lowering drug atorvastatin as an adjunct in the management of diabetic macular edema. Am J Ophthalmol. 2004;137:675-82.

52. Panagiotoglou TD, Ganotakis ES, Kymionis GD, Moschandreas JA, Fanti GN Charisis SK, Malliaraki NE, Tsilimbaris MK. Atorvastatin for diabetic macular edema in patients with diabetes mellitus and elevated serum cholesterol. Ophthalmic Surg Lasers Imaging. 2010;41:316-22.

53. King RC, Dobree JH, Kok D, Foulds WS, Dangerfield WG. Exudative diabetic retinopaty. Spontaneous changes and effects of a corn oil diet. $\mathrm{Br} J$ Ophthalmol. 1963:47:666-72

54. Cusick M, Chew EY, Chan CC, Kruth HS, Murphy RP, Ferris FL 3rd. Histopathology and regression of retinal hard exudates in diabetic retinopathy after reduction of elevated serum lipid levels. Ophthalmology. 2003;110:2126-33.

55. Preiss D, Seshasai SR, Welsh P, Murphy SA, Ho JE, Waters DD, DeMicco DA, Barter P, Cannon CP, Sabatine MS, Braunwald E, Kastelein JJ, de Lemos JA, Blazing MA, Pedersen TR, Tikkanen MJ, Sattar N, Ray KK. Risk of incident diabetes with intensive-dose compared with moderate-dose statin therapy: a meta-analysis. JAMA. 2011:305:2556-64.

56. Sheely D, Jialal I. Strategies to lower low-density lipoprotein cholesterol in metabolic syndrome: averting the diabetes risk. Metab Syndr Relat Disord. 2013;11:149-51.

57. Romero P, Baget M, Mendez I, Fernández J, Salvat M, Martinez I. Diabetic macular edema and its relationship to renal microangiopathy: a sample of type I diabetes mellitus patients in a 15-year follow-up study. J Diabetes Complicat. 2007;21:172-80.

58. Mohamed Q, Gillies MC, Wong TY. Management of diabetic retinopathy. A systematic review. JAMA. 2007:298:902-16.

59. Klein R, Knudtson MD, Lee KE, Gangnon R, Klein BEK. The Wisconsin epidemiologic study of diabetic retinopathy XXIII. The twenty-five year incidence of macular edema in persons with type 1 diabetes. Ophthalmology. 2009;116:497-503.

60. Klein R, Klein BEK, Moss SE, Cruickshanks KJ. The 14-year incidence and progression of diabetic retinopathy and associated risk factors in type 1 diabetes. Ophthalmology. 1998;105:1801-15. 
61. Lattanzio R, Brancato R, Pierro L, Bandello F, laccheri B, Fiore T, Maestranzi G. Macular thickness measured by optical coherence tomography (OCT) in diabetic patients. Eur J Ophthalmol. 2002;12:482-7.

62. Browning DJ, Fraser CM, Clark S. The relationship of macular thickness to clinically graded diabetic retinopathy severity in eyes without clinically detected diabetic macular edema. Ophthalmology. 2007;115:533-9.

63. Igersheimer J. Intraocular pressure and its relation to retinal extravasation. Arch Ophthalmol. 1944;32:50-5.

64. Jeganathan VS, Wang JJ, Wong TY. Ocular associations of diabetes other than diabetic retinopathy. Diabetes Care. 2008;31:1905-12.

65. Chiang PP, Lamoureux EL, Zheng Y, Tay WT, Mitchell P, Wang JJ, Wong TY. Frequency and risk factors of non-retinopathy ocular conditions in people with diabetes: the Singapore Malay eye study. Diabet Med. 2013;30:e32-40.

66. Fineman MS, Benson WE, Scott IU. Cataract management in diabetes. In: Scott IU, Flynn HW, Smiddy WE, editors. Diabetes and ocular disease: past, present and future therapies. Second edition. Oxford University Press; 2010. p.301-319.

67. Patel JI, Hykin PG, Cree IA. Diabetic cataract removal: postoperative progression of maculopathy — growth factor and clinical analysis. Br J Ophthalmol. 2006;90: 697-701.

68. Klein R, Klein BE, Moss SE, Cruickshanks KJ. The Wisconsin epidemiologic study of diabetic retinopathy. XV. The long-term incidence of macular edema. Ophthalmology. 1995;102:7-16.

69. Kim SJ, Equi R, Bressler NM. Analysis of macular edema after cataract surgery in patients with diabetes using optical coherence tomography. Ophthalmology. 2007:114:881-9.

\section{Submit your next manuscript to BioMed Central and we will help you at every step:}

- We accept pre-submission inquiries

- Our selector tool helps you to find the most relevant journal

- We provide round the clock customer support

- Convenient online submission

- Thorough peer review

- Inclusion in PubMed and all major indexing services

- Maximum visibility for your research

Submit your manuscript at www.biomedcentral.com/submit

C) Biomed Central 